\title{
Effectiveness of a Video Teaching Programme Regarding Tracheostomy Care on Knowledge and Skills of Care Providers of Tracheostomized Patients at AIIMS, New Delhi
}

\author{
Amandeep Kaur ${ }^{1}$, Ashia Qureshi \\ ${ }^{1}$ Assistant. Professor, Amity College of Nursing, Amity University, Gurgaon, Haryana \\ ${ }^{2}$ Dean cum Principal, Galgotia College of Nursing, Galgotia University, Greater Noida, UP
}

\begin{abstract}
Background of the study: Patient education facilitates imparting information to the patients and their caregivers by the health professionals. The obligation of pre-discharge patient and care providers education and ensuring standard care at home for the patients with a lifelong tracheostomy is emphasized. These patients require a cautious and meticulous home care of the tracheostomy tube and the stoma. ${ }^{1}$.Aim: To develop an effective video based learning resource material about tracheostomy care in adults, for providing knowledge and developing skills of care providers, for providing home care to the patients discharged from the hospital with tracheostomy tube in-situ Methodology: Pre-Experimental research design (one group pre test post test design) on 29 care providers from neurosurgery and neurology wards, AIIMS, New Delhi. Purposive sampling technique was used and data collection was done by using a knowledge questionnaire and observation checklist. Results: The pre test, post test I and post test II mean knowledge scores were $12.3 \pm 2.2,18.6 \pm 1.2$ and $18.2 \pm 1.4$ respectively. The mean pre test, post test I and post test II skill scores were $38.2 \pm 7.3,74.4$ \pm 6.7 and $71.7 \pm 6.9$ respectively. The mean post test knowledge and skills scores at post test I and post test II were significantly higher as compared to the pre test knowledge and skills scores at $p<0.000$ level of significance. Conclusion: The video teaching program was found effective in bringing about an increase in knowledge and effective skills of care providers regarding tracheostomy care in adults. So, the video as a teaching tool can be utilized by nurses in providing discharge teaching to the tracheostomized patients and their care providers.
\end{abstract}

Keywords: Effectiveness, Video teaching Programme, Tracheostomy care, Care providers, Tracheostomized Patients

\section{Introduction}

Respiratory system is one of the vital systems of our body. Its primary purpose is the exchange of gases. Any respiratory obstruction will affect the oxygen supply to the cerebral cells leading to cerebral hypoxia which will result in deterioration of neurological status of the patient and may lead to death. This is particularly important in patients suffering from neurological disorders as oxygen is required for the survival of brain cells. Patients who are unable to maintain their own ventilation, an artificial assistance in the form of endotracheal intubation and tracheostomy may be required. $^{2}$

Tracheostomy is one of the most common procedures performed in intensive care unit. $^{3}$ A tracheostomy is an incision into the trachea that forms a temporary or permanent opening to allow airflow and permit the removal of bronchotracheal secretions. ${ }^{4} \mathrm{~A}$ tracheostomy may be performed as an emergency or planned procedure. The aim of tracheostomy is to bypass obstruction in the upper airway; to aid prolonged and assisted ventilation; and to facilitate the removal of respiratory secretions.

The patient leaving the hospital with a new tracheostomy will face problems with secretion management, increased risk of infections, alterations in body image \& impaired vocalization. To ensure a safe transition from the hospital to home, the patient and family must demonstrate competence in all aspects of tracheostomy care, able to recognize signs and symptoms that should be reported to the physician and have adequate support at home. Nurses can help a patient successfully manage these problems through comprehensive discharge planning. ${ }^{6}$

Patients having neurological and neurosurgical conditions may have neurological deficit and some are in unconscious state. These factors render their ability of self-care of TT insitu and make them partially or fully dependent on their care providers. This fact imposes the need to teach the care providers about tracheostomy care of their patient, so that they can perform it safely and properly.

A review of tracheostomy videos concluded that audiovisual materials like video recordings can be useful as a basis for an educational session or as a substitute when the specialty nurse is unavailable to provide education. ${ }^{7}$

However; there were no studies available on use of videoteaching program for the training of care providers for home care of tracheostomy of their patient. Hence, researcher felt the need to develop a video teaching program to teach the care providers about tracheostomy care of their patient.

\section{Literature Survey}

C.(T.) Tolomeo et al., conducted a quality improvement (QI) project to standardize care and skills proficiency training to parents of infants with a tracheostomy tube in preparation for discharge to home. A convenience sample of 


\section{International Journal of Science and Research (IJSR) \\ ISSN (Online): 2319-7064}

Index Copernicus Value (2015): 78.96 | Impact Factor (2015): 6.391

infants with a tracheostomy tube admitted to the Pediatric Respiratory Care Unit were included in the study. Descriptive statistics were used to analyze the results. Results revealed that through this QI approach, the time required by parents to achieve proficiency in the care of a technology dependent infant was decreased, the length of stay for these infants was also reduced, and increase referral of the infants for developmental assessment. ${ }^{8}$

Loerzel VW, Crosby WW, Reising $\mathbf{E}$ et al., describes the development and outcomes of the Tracheostomy Care Anxiety Relief Through Education and Support (T-CARES) program, developed in response to high readmission rates for patients with head and neck cancer discharged with a tracheostomy. T-CARES consists of an 18-minute video demonstration, group discussion, return demonstration, and skills assessment. The course also incorporates hands-on practice on a low-cost anatomical task trainer created by the authors. A significant reduction in caregiver anxiety was noted after participation in the T-CARES program. TCARES and similar programs can be developed to teach self-care for a variety of conditions that patients and caregivers are expected to manage at home. ${ }^{9}$

Nagi M, Kapoor S, Kaur $\mathbf{S}$ et al., conducted an experimental study about the effect of an intervention on the performance regarding change of Tracheostomy Tube (TT) among the caregivers of the patients who are going to be discharged with a TT in situ from neurosurgery units of a tertiary care hospital. Sixty-four subjects were purposely selected. The tools used were identification data sheet and an observation checklist on the change of TT. First, the caregivers were observed during change of TT. Then, each subject was demonstrated the right technique of change of tube. Result revealed that before demonstration, only one subject had some knowledge about the change of TT. After $72 \mathrm{~h}$ of demonstration, the score was $12.34 \pm 1.6(77.2 \%)$. Study concluded that the caregivers should be properly trained regarding changing the TT in order to prevent any complication while performing the procedure. The results of this study provide further strategies for other caregiver guidance programmes. ${ }^{10}$

Sharma B conducted a quasi experimental study in Vinayaka Mission Hospital, Salem to assess the effectiveness of video assisted teaching module on tracheostomy care on 50 staff nurses. Findings revealed that overall post-test mean score was $23.58 \pm 2.21$ which was $78.6 \%$ of the total score, revealed good knowledge of staff nurses. The difference in mean percentage between pre and post-test was around $27.4 \%$ shows that video assisted teaching module was effective in improving the knowledge of staff nurses regarding tracheostomy care. Overall post-test mean skill score was $26 \pm 3.38$ which was $74.28 \%$ of the total score revealing good performance of staff nurses on tracheostomy care. The difference in mean percentage between pre and post-test was around $24.8 \%$ shows that video assisted teaching module was effective in improving the skill of staff nurses in performing tracheostomy care. ${ }^{11}$

Cetto R, Arora A, Hettige R, et al,. conducted a cohort study, which highlighted that the suboptimal standards in tracheostomy care have been a growing concern in view of the increasing demands for ICU. With the introduction of Tracheostomy Care Bundle checklist, a dedicated Tracheostomy Multi-disciplinary Team and an educational programme, the time to decannulation following ICU discharge decreased from 21 days to 11 days; as did the mean total tracheostomy time, from 34 days to 25 days; the number of critical incidents substantially declined from 58 to 7. ${ }^{12}$

Graf MJ, Montagnino BA, Hueckel R, et al., conducted a study which revealed that caregivers of patients with new tracheostomies needed a median of 14 days to successfully complete a tracheostomy care training program. Discharge occurred at median of 6.5 days after education was completed. They concluded that a structured education and discharge program for caregivers may result in a shorter length of stay for patients with new tracheostomies. ${ }^{13}$

\section{Statement of the Problem}

"A study to assess the effectiveness of video teaching program regarding tracheostomy care on knowledge and skills of care providers of adult patients with tracheostomy tube in-situ in Neuro-sciences centre of AIIMS, New Delhi."

\section{Objective of the Study:}

To evaluate the effectiveness of video teaching program on tracheostomy care in improving knowledge and skills of care providers of adults patients with tracheostomy tube (TT) insitu.

\section{Hypotheses:}

$\mathrm{H}_{1^{-}}$The knowledge score of the care providers of adult patients with TT in-situ regarding tracheostomy care both immediately and two weeks after the video teaching program will be higher as compared to the baseline knowledge score at 0.05 level of significance, as assessed by self-administered knowledge questionnaire.

$\mathrm{H}_{2^{-}}$The skills score of the care providers of adult patients with TT in-situ regarding tracheostomy care both immediately and two weeks after the video teaching program will be higher as compared to the baseline skill score at 0.05 level of significance, as assessed by observation checklist.

\section{Conceptual Framework}

The present study was focused on assessing the knowledge and skills regarding tracheostomy care among care providers of patients with tracheostomy tube in-situ by applying General System theory Developed by Ludwig Von Bertalanffy (1969).

\section{Operational Definition:}

- Tracheostomy care- Refers to monitoring for signs and symptoms of respiratory distress, tracheostomy suctioning, tracheostomy hygiene, managing blocked tube and emergency decannulation \& signs and symptoms to report immediately to the physician.

\section{Volume 6 Issue 7, July 2017 www.ijsr.net}




\section{International Journal of Science and Research (IJSR) \\ ISSN (Online): 2319-7064}

Index Copernicus Value (2015): 78.96 | Impact Factor (2015): 6.391

- Tracheostomy Suctioning - Refers to mechanical aspiration of excess pulmonary secretions from an artificial airway (tracheostomy tube) placed in a patient by a rubber or polythene catheter.

- Tracheostomy hygiene- Refers to cleaning of inner cannula in case of metallic tube, cleaning of area around tracheostomy with boiled cool water, applying sterile dressing under the neck plate of TT and changing the soiled neck threads.

- Care providers - Refers to relatives, friends of patient and other paid workers involved in the care of patients in the hospital and at home for more than 8 hours.

- Video teaching program -In this study it refers to the systematically designed individualized teaching program to educate care providers of adult patient with TT in situ with the help of video made by the researcher on tracheostomy care in adults which includes anatomy and physiology of respiratory system, Tracheostomy suction, Tracheostomy hygiene, Management of blocked tubes, Management of emergency decannulation.

- Effectiveness - Refers to significant increase in the level of knowledge and skills of care providers of adult patient with TT in situ which is measured from the response of pre test, Video teaching Programme and post test.

\section{Methodology}

Research Approach: Quantitative, experimental approach

Research Design Pre-Experimental research Design (one group pretest and posttest design)

Setting: The present study was conducted in Neurology and Neurosurgery wards of Neuro-sciences center of All India Institute of Medical Sciences (AIIMS), New Delhi.

\section{Variables:}

Independent variable

Video teaching program on tracheostomy care in adults.

Dependent variable

Care providers' knowledge regarding tracheostomy care in adults.

Care providers' skills regarding tracheostomy care in adults.

Extraneous variable

Care provider's age, Care provider's sex, Education of the care provider, Days on tracheostomy,

Previous participation in educational programs on tracheostomy care, Performance of tracheostomy care before participating in this study.

Population: Care providers of adult patients with tracheostomy tube in-situ in AIIMS hospital, New Delhi

Sample: Care providers of adult patients with tracheostomy tube in-situ in AIIMS hospital, New Delhi who met the eligibility criteria.

Sample Size: The sample size of the present study comprises 29 Care providers of adult patients with tracheostomy tube in-situ in AIIMS hospital, New Delhi

Sampling Technique: Purposive sampling technique was used to collect the sample

\section{Inclusion criteria}

1) Care providers of all patients (age >18yrs) with tracheostomy admitted in Neurology and Neurosurgery wards (NS-2, NS-3, NS-4, NS-5) of Neuro-sciences center of AIIMS, New Delhi.

2) Care provider providing the care to their patient in the hospital and at home for more than 8 hours a day.

3) Care provider age range between 18 to 50 years.

4) Able to understand Hindi or English.

\section{Exclusion criterion}

1) Care providers who were not willing to participate in the study.

2) Care providers of all tracheostomy patients with following conditions were excluded:

- Tumors of trachea or larynx

- Congenital abnormalities of airway

- Trauma - accidental and surgical of trachea or larynx

- Foreign bodies in airway

- Vocal cord paralysis

\section{Tools for Collection of Data:}

1) Demographic datasheet: Demographic profile of care providers.

2) Knowledge questionnaire (20 items) on tracheostomy care to assess the knowledge of care providers regarding tracheostomy care before and after intervention.

3) An observational checklist (78 items) to assess the skills of care providers regarding tracheostomy care before and after intervention.

Content validity of knowledge questionnaire and observational checklist was obtained. Both the tools were found reliable with the reliability co-efficient of 0.93 and 0.91 respectively.

\section{Development of video teaching program on tracheostomy care in adults}

A 18 minute video teaching on tracheostomy care in adults was prepared based on the American Association of Respiratory guidelines on suctioning of the patient at home $(1999)^{14}$ and other guidelines given by National Health Services (NHS) trust hospital ${ }^{15}$ and various universities ${ }^{16-18}$ for patients about home care of tracheostomy. Video was made in hindi as well as english.

Ethical Considerations: The ethics committee of AIIMS approved the study protocol. Informed written consent was taken from all the participants. Confidentiality and privacy of the information given by the participants was maintained throughout the study period.

\section{Pilot Study:}

Pilot study was done among 10 care providers of adult tracheostomized patients and study was found to be feasible.

\section{Data collection procedure:}

Table 1: Method of Collection of Data

\begin{tabular}{|c|c|c|c|c|c|}
\hline \multirow[b]{2}{*}{ Pre test } & \multirow[b]{2}{*}{ Intervention } & \multicolumn{4}{|c|}{ Post test } \\
\hline & & $\begin{array}{l}\text { Same } \\
\text { inter }\end{array}$ & $\begin{array}{l}\text { day of } \\
\text { ention }\end{array}$ & $\begin{array}{r}\text { Two } n \\
\text { inte }\end{array}$ & $\begin{array}{l}\text { safter } \\
\text { tion }\end{array}$ \\
\hline \begin{tabular}{l|l}
$\mathrm{OK}_{1}$ & $\mathrm{OS}_{1}$
\end{tabular} & $X$ & $\mathrm{OK}_{2}$ & $\mathrm{OS}_{2}$ & $\mathrm{OK}_{3}$ & $\mathrm{OS}_{3}$ \\
\hline
\end{tabular}

$O$ - Observation, K- Knowledge and S-Skills 


\section{International Journal of Science and Research (IJSR) \\ ISSN (Online): 2319-7064}

Index Copernicus Value (2015): 78.96 | Impact Factor (2015): 6.391

Teaching programme $(\mathrm{X})$ was conducted as per the prepared lesson plan based on video teaching. It was conducted as one to one teaching. Method of teaching was lecture cum discussion and projection of the video teaching programme on tracheostomy care. The equipment used was a laptop computer to play the video. Duration of the intervention was 25-30 minutes.

\section{Results}

Table 2: Frequency and percentage Distribution of Care

\begin{tabular}{|c|c|c|}
\hline \multicolumn{2}{|c}{ providers, N=29 } & Range \\
\hline Demographic variables & Median & $20-50$ years \\
\hline Age (years) & 33 years & $8-24$ hours \\
\hline $\begin{array}{c}\text { Duration of stay with pt } \\
\text { (hrs) }\end{array}$ & 12 hours & \\
\hline \multirow{3}{*}{ Sex } & Frequency (\%) & $15(51.7)$ \\
\cline { 2 - 3 } Marital status & Male & $14(48.3)$ \\
\cline { 2 - 3 } & Female & $15(51.7)$ \\
\cline { 2 - 3 } & Married & $10(34.5)$ \\
\hline Relation with patient & Onmarried & $4(13.8)$ \\
\cline { 2 - 3 } & Spouse & $4(13.8)$ \\
\cline { 2 - 3 } & Sibling & $10(34.5)$ \\
\cline { 2 - 3 } & Son/daughter & $7(24.1)$ \\
\hline \multirow{4}{*}{ Self health status } & Parents & $8(27.6)$ \\
\cline { 2 - 3 } & Healthy & $27(93.1)$ \\
\cline { 2 - 3 } & Any chronic illness & $2(6.9)$ \\
\hline Ony infectious disease & - \\
\hline \multirow{4}{*}{ Occupation } & Unemployed & $14(48.3)$ \\
\cline { 2 - 3 } & Employed & $14(48.3)$ \\
\cline { 2 - 3 } & In health sector & $1(3.4)$ \\
\hline Education & Able to read and write & $5(17.2)$ \\
\cline { 2 - 3 } & Primary & $3(10.3)$ \\
\cline { 2 - 3 } & Secondary & $5(17.2)$ \\
\cline { 2 - 3 } & Higher secondary & $5(17.2)$ \\
\hline
\end{tabular}

\begin{tabular}{|c|c|c|}
\hline & Graduation & $8(27.6)$ \\
\cline { 2 - 3 } & Post-graduation \& above & $3(10.3)$ \\
\hline \multirow{2}{*}{$\begin{array}{c}\text { Attended any other } \\
\text { educational program on } \\
\text { tracheostomy care }\end{array}$} & Yes & $5(17.2)$ \\
\cline { 2 - 3 } & No & $24(82.8)$ \\
\hline Performed TT care before & Yes & $4(13.8)$ \\
\cline { 2 - 3 } & No & $25(86.2)$ \\
\hline If yes, how many times & Not performed & $25(86.3)$ \\
\cline { 2 - 3 } & $1-25$ times & $2(6.9)$ \\
\cline { 2 - 3 } & $26-50$ times & $1(3.4)$ \\
\cline { 2 - 3 } & $>50$ times & $1(3.4)$ \\
\hline
\end{tabular}

Table 2 depicts that the care providers under the study had a median age of 33 years and 12 hours duration of stay with the patient. Almost equal numbers of care providers were males $(51.7 \%)$ and females $(48.3 \%)$. Majority of the care providers were married $(51.7 \%)$, healthy $(93.1 \%)$, related to patient as their sibling (34.5\%) and had educational qualification of Graduation and above $(37.9 \%)$. Of the total employed care providers $(51.7 \%)$, only $3.4 \%$ were working in health care sector. Very few care providers had attended any other educational program on tracheostomy care (17.2 $\%)$. Out of $(13.8 \%)$ care providers who had performed tracheostomy care before this study, equal number of care providers performed it up to 1-25 times $(6.9 \%)$ and for $>26$ times $(6.8 \%)$.

Table 3: Pre test, post test I, and post test II knowledge scores $\mathrm{N}=29$

\begin{tabular}{|c|c|c|c|}
\hline & $\begin{array}{c}\text { Pre test } \\
\text { Mean } \pm \\
\text { SD }\end{array}$ & $\begin{array}{c}\text { Post test I } \\
\text { (Immediately } \\
\text { after) } \\
\text { Mean } \pm \text { SD }\end{array}$ & $\begin{array}{c}\text { Post test II } \\
\text { (two weeks after) } \\
\text { Mean } \pm \text { SD }\end{array}$ \\
\hline $\begin{array}{c}\text { Knowledge } \\
\text { score }\end{array}$ & $12.3 \pm 2.2$ & $18.6 \pm 1.2$ & $18.2 \pm 1.4$ \\
\hline
\end{tabular}

Maximum score $=20$

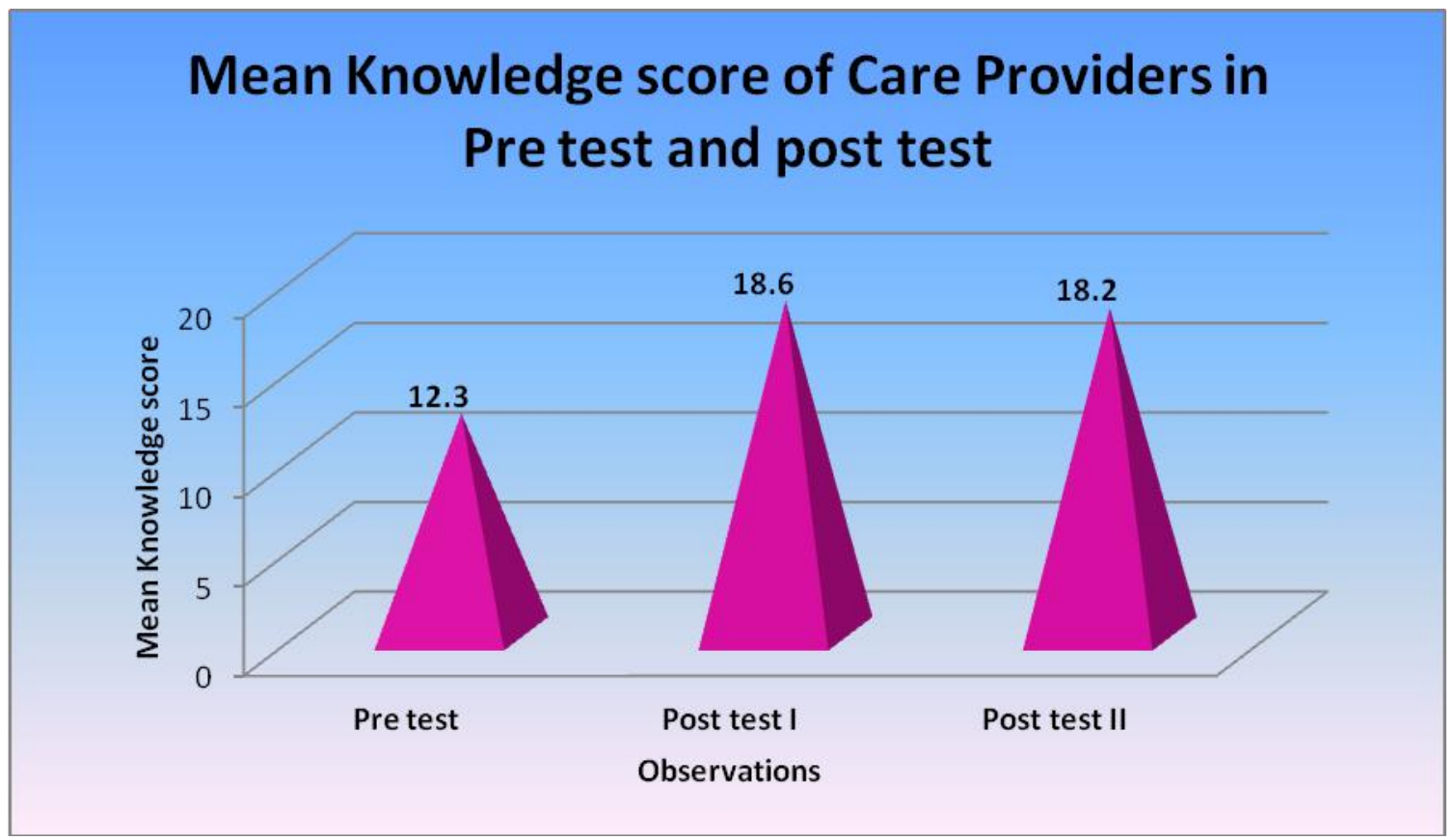

Figure 1: Simple Pyramid diagram represents mean pre test, post test knowledge scores of Care providers

Table 3 and Fig 1 shows that the pre test, post test I, and post test II mean knowledge scores are $12.3 \pm 2.2,18.6 \pm 1.2$ and $18.2 \pm 1.4$ respectively. It shows an increase in mean post test scores from the mean pre test score and slight

\section{Volume 6 Issue 7, July 2017 www.ijsr.net}




\section{International Journal of Science and Research (IJSR) \\ ISSN (Online): 2319-7064 \\ Index Copernicus Value (2015): 78.96 | Impact Factor (2015): 6.391}

decrease in mean score of post test II as compared with the mean score of post test I.

Table 4: Comparison of pre test and post test knowledge scores, $\mathrm{N}=29$

\begin{tabular}{|l|l|c|c|c|c|c|}
\hline & & \multirow{2}{*}{$\begin{array}{c}\text { Mean } \\
\text { Factor 1 }\end{array}$} & Factor 2 & Std. & $\mathrm{p}$ & \multicolumn{2}{|c|}{$\begin{array}{c}95 \% \text { CI for } \\
\text { difference }\end{array}$} \\
\cline { 5 - 7 } & & (Factor 1-2 $)$ & Error & value & $\begin{array}{c}\text { Lower } \\
\text { bound }\end{array}$ & $\begin{array}{c}\text { Upper } \\
\text { bound }\end{array}$ \\
\hline Pre test & Post test I & -6.35 & 0.31 & $0.000^{\mathrm{a}^{*}}$ & -7.13 & -5.56 \\
\hline Pre test & Post test II & -5.93 & 0.32 & $0.000^{\mathrm{a}^{*}}$ & -6.75 & -5.11 \\
\hline Post test I Post test II & 0.41 & 0.13 & $0.009^{\mathrm{a}^{*}}$ & 0.09 & 0.74 \\
\hline
\end{tabular}

a- Repeated measures ANOVA with Bonferroni correction,

*- statistically significant, $p<0.05$

Table 4 depicts that knowledge score at post test I and post test II are significantly higher as compared to the pre test knowledge score at $\mathrm{p}=0.000$ level. Also the slight decrease in knowledge score from post test I to post test II is found to be statistically significant at $p=0.009$ which can be attributed to very small SD (0.13) between these groups. Hence the slight decrease in knowledge score from post test I to post test II is found to be statistically significant but is not clinically significant.
Hypothesis Testing: In the light of the above findings, the research hypothesis $\mathbf{H}_{1}$ i.e. the knowledge score of the care providers of adult patient with TT in-situ regarding tracheostomy care both immediately and two weeks after the video teaching program will be higher as compared to the baseline knowledge score at 0.05 level of significance as assessed by self-administered knowledge questionnaire, is accepted and null hypothesis is rejected. Thus it is concluded that the video teaching program is found to be effective in bringing about an increase in knowledge of the care providers of adult patients with TT in-situ regarding tracheostomy care both immediately and two weeks after the video teaching program.

Table 5: Mean Pre test, post test I, and post test II skills scores, $\mathrm{N}=29$

\begin{tabular}{|l|c|c|c|}
\hline & $\begin{array}{c}\text { Pre test } \\
\text { Mean } \pm \text { SD }\end{array}$ & $\begin{array}{c}\text { Post test I } \\
\text { (Immediately after) } \\
\text { Mean } \pm \text { SD }\end{array}$ & $\begin{array}{c}\text { Post test II } \\
\text { (two weeks after) } \\
\text { Mean } \pm \text { SD }\end{array}$ \\
\hline Skills score & $38.2 \pm 7.3$ & $74.4 \pm 6.7$ & $71.7 \pm 6.9$ \\
\hline
\end{tabular}

Maximum score $=82$

\section{Mean skills score of Care Providers in Pre test and post test}

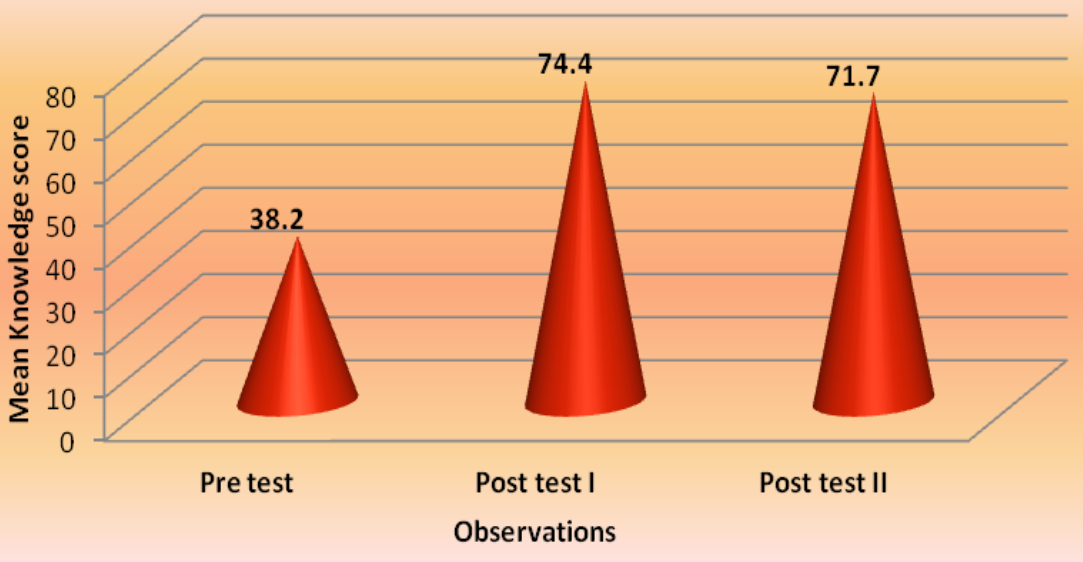

Figure 2: Simple Conical diagram represents mean pre test, post test skills scores of Care providers

Table 5 and Fig 2 shows that the pre test, post test I, and post test II mean skill scores are found to be $38.2 \pm 7.3,74.4 \pm$ 6.7 and $71.7 \pm 6.9$ respectively, as seen from table 4 above. It shows an increase in mean post test scores from the mean pre test scores and slight decrease in mean scores of post test II as compared to that of post test I scores.

Table 6: Comparison of pre test and post test skills scores, $\mathrm{N}=29$

\begin{tabular}{|c|c|c|c|c|c|c|}
\hline & & \multirow{2}{*}{$\begin{array}{c}\text { Mean } \\
\text { Fafference }\end{array}$} & \multirow{2}{*}{$\begin{array}{c}\text { Std. } \\
\text { Error }\end{array}$} & p value & \multicolumn{2}{|c|}{$\begin{array}{c}\text { 95\% CI for } \\
\text { difference }\end{array}$} \\
\cline { 5 - 8 } & Factor 2 & $\begin{array}{c}\text { Lower } \\
\text { bound }\end{array}$ & $\begin{array}{c}\text { Upper } \\
\text { bound }\end{array}$ \\
\hline Pre test & Post test I & -36.16 & 1.03 & $0.000^{\mathrm{a}^{*}}$ & -38.79 & -33.53 \\
\hline Pre- test & Post test II & -33.41 & 1.8 & $0.000^{\mathrm{a}^{*}}$ & -38.01 & -28.82 \\
\hline Post test I & Post test II & 2.75 & 1.9 & 0.477 & -2.09 & 7.59 \\
\hline
\end{tabular}

a- Repeated measures ANOVA with Bonferroni correction, *- statistically significant, $p<0.05$

Table 6 signifies that skills score at post test I and post test II are significantly higher as compared to the pre test skills score at $\mathrm{p}=0.000$ level. As interpreted from the table above, the skills score between post test I and post test II are not found to be statistically significant $(\mathrm{p}=0.477)$.

Hypothesis Testing: In the light of the above findings, the research hypothesis $\mathbf{H}_{2}$ i.e. the skills score of the care providers of adult patient with TT in-situ regarding tracheostomy care both immediately and two weeks after the video-teaching program will be higher as compared to the baseline skill score at 0.05 level of significance as assessed by observation checklist, is accepted and the null hypothesis is rejected. It is concluded that the video teaching program is 


\section{International Journal of Science and Research (IJSR) \\ ISSN (Online): 2319-7064}

Index Copernicus Value (2015): 78.96 | Impact Factor (2015): 6.391

found to be effective in bringing about an increase in skills level of the care providers of adult patients with TT in-situ regarding tracheostomy care both immediately and two weeks after the video teaching program.

\section{Major Findings and Discussion}

Results of the present study were in congruence with a research conducted by Kun SS, et al, to assess the knowledge of 152 primary caregivers, using a 25 -question survey regarding how to handle emergency situations with tracheostomies or malfunction of the ventilators at home after a respiratory therapist driven training program. The result depicted increase in the mean knowledge score of $80 \%$ after the training program. ${ }^{19}$

The results were also similar to the study done by Nagi M, Kapoor S, Kaur S, et al., that compared tracheostomy tube change procedure skills among the caregivers of the patients who were going to be discharged with tracheostomy tube in situ before and after a demonstration of tracheostomy tracheostomy tube change procedure and providing them an information booklet. The result showed that the mean performance score was $0.16 \pm 1.3$, before the demonstration which increased to $12.34 \pm 1.6$ in the return demonstration taken after 72 hours. $(\mathrm{t}=-48.17,63, \mathrm{P}<0.0001) .10$

\section{Conclusion}

The video teaching program was effective in bringing about an increase in knowledge of the care providers of adult patients with TT in-situ regarding tracheostomy care both immediately and two weeks after the video-teaching program. The video teaching program was effective in bringing about an increase in skills level of the care providers of adult patients with TT in-situ regarding tracheostomy care both immediately and two weeks after the video-teaching program. The improvement in knowledge and skills generally sustained two weeks after the video teaching program.

\section{Nursing Implication}

The findings of the present study have implication for Nursing Education, Nursing Administration, Nursing Practice, and nursing Research.

\section{Nursing practice}

- A video can be used to give discharge teaching to patients and care providers, thus, saving the time of nursing staff and excluding the risk of missing a step of the procedure.

- It can also be used by community health nurses to reinforce the teaching to patients and care providers after discharge from hospital and at home.

\section{Nursing education}

The video can be utilized in teaching nursing students about home care of tracheostomy during their course so that they can practice it during their ward postings for teaching the care providers about home care of tracheostomy before discharge.

\section{Nursing research}

- Conduct research to increase knowledge and skills of staff members regarding home care of tracheostomy.

- Conduct research to develop a video on tracheostomy care to increase knowledge and skills of new staff members regarding tracheostomy care practiced in wards.

- Develop other new innovative media for teaching patients and care providers in wards and community.

- Develop video as a health education tool for providing education to the patients and care providers in wards and community for health promotion and disease prevention.

\section{Nursing administration}

Video should be made available to the nursing staff in all the wards so that they can utilize it for providing discharge teaching to the patients.

\section{Limitations}

- Small sample size.

- Purposive sampling was used.

- Single setting was used; hence results cannot be generalized to other settings.

- The contamination which might have happened due to discussions among care providers in the absence of researcher and observation of skills of nurses performing tracheostomy care in wards after and before the assessment could not be avoided.

\section{Recommendations}

Based on the findings of the study, the following recommendations are offered for future research.

- Study can be replicated in multiple settings like ENT wards, trauma wards, oncology wards including neurology and neurosurgery wards.

- A study with longer duration follow up can be taken up to have more evidence about the retention of knowledge and skill and also to observe the outcome of the patient after such a teaching program.

- The prepared video can be used to teach staff regarding home care of tracheostomy so as to improve their knowledge and skills and thus, the quality of discharge teaching.

- A similar study can be replicated with an aim to develop instructional video on other skill based procedure to improve knowledge and skill of patients and care providers.

\section{References}

[1] Rabiul Alam, Mahbuba Rehana and Abdullah Raied. Obligation of home care education for tracheostomy. Safety in Health 2017 3:2. Available From: https://safetyinhealth.biomedcentral.com/articles/10.118 6/s40886-017-0053-x

[2] Hickey JV. The Clinical practice of Neurology and Neurological Nursing. Philadelphia: J.B Lippincott; 2005.

[3] Durbin CG. Indications for and Timing of Tracheotomy. Respiratory Care. 2005;50:483- 487 


\section{International Journal of Science and Research (IJSR) \\ ISSN (Online): 2319-7064 \\ Index Copernicus Value (2015): 78.96 | Impact Factor (2015): 6.391}

[4] Seay SJ, Gay SL, Strauss M. Tracheostomy Emergencies. AJN. March 2002 ; 102:59-63

[5] Serra A, Curie EM. Tracheostomy care. Nursing Standard. July 5;14:45-52.

[6] Wilson EB, Malley N. Discharge planning for the patient with a new tracheostomy. Crit Care Nurse. 1990;10:73-9.

[7] Rudy SF. Review of tracheostomy videos for staff education. ORL Head Neck Nurs. 1997;15:15-9.

[8] C.(T.) Tolomeo et al. Standardizing Care and Parental Training to Improve Training Duration, Referral Frequency, and Length of Stay: Our Quality Improvement Project Experience. Journal of Pediatric Nursing 32 (2017) 72-79.Available From: http://www.pediatricnursing.org/article/S08825963(16)30354-2/pdf

[9] Loerzel VW, Crosby WW, Reising E, et al., Developing the Tracheostomy Care Anxiety Relief Through Education and Support (T-CARES) Program. Clin J Oncol Nurs. 2014 Oct;18(5):522-7. doi: 10.1188/14.CJON.522-527.Available From: https://www.ncbi.nlm.nih.gov/pubmed/25253106

[10] Nagi M, Kapoor S, Kaur S, Gupta SK. Effect of an intervention on performance regarding change of tracheostomy tube among the caregivers of the patient. Indian J Neurosurg 2014;3:31-5.

[11]Bhartendra Sharma. A Quasi-Experimental Study to Assess the Effect of Video Assisted Teaching Module Regarding Tracheostomy Care on Knowledge and Skill of Staff Nurses at Vinayaka Mission Hospital, Salem, Tamilnadu. Research J. Pharm. and Tech. 7(7): July 2014 Page 737-742. Available From: http://rjptonline.org/AbstractView.aspx?PID=2014-7-711

[12] Cetto R, Arora A, Hettige R, Nel M, Benjamin L, Gomez $\mathrm{CM}$ et al. Improving tracheostomy care: a prospective study of the multidisciplinary approach. Clinical Otolaryngology. 2011; 36:482-488.

[13] Graf MJ, Montagnino BA, Hueckel R, McPherson ML. Children with new tracheostomies: Planning for family education and common impediments to discharge. Pediatric Pulmonology. 2008;43:788-94.

[14] AARC Clinical Practice Guidelines. Suctioning of the patient in the home. Respir Care. 1999;44:99-104.

[15] Plymouth Hospitals NHS Trust and Plymouth Community Healthcare. Tracheostomy Care Guidelines Discharge Process [Internet];2012Feb8.Availablefrom: http://www.plymouthcommunityhealthcare.co.uk/image s/uploads/content/Policies/T/Tracheostomy_Guidelines v1.pdf

[16] University of Pittsburgh Medical Center. Tracheostomy care [Internet];2007. Available from: http://www.upmc.com/patientsvisitors/education/docum ents/tracheostomycare.pdf

[17] Queen Elizabeth II Health Sciences Centre. Nova Scotia. Tracheostomy care at home [Internet]; 2004 Jan. Available from: http://www.cdha.nshealth.ca/patientinformation/nshealt hnet/0244.pdf

[18] University of Kentucky. Home tracheostomy care. [Internet];2003 May. Available from:http://www.tracheostomy.com/resources/pdf/unive rsity_kentucky.pdf
[19] Kun SS, Davidson-Ward SL, Hulse LM, Keens TG. How Much Do Primary Care Givers Know About Tracheostomy and Home Ventilator Emergency Care? Pediatric Pulmonology. 2010; 45:270-274

\section{Author Profile}

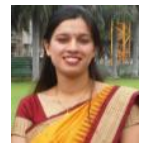

Amandeep Kaur is Assistant Professor, Amity College of Nursing, Amity University, Gurgaon. She has worked as a Lecturer at Rural nursing training institute, Rural Institute of health and paramedical sciences, Sonepat, Haryana for a period of 1 Year and as a Clinical Instructor at Saraswati college of nursing, Saraswati Professional and Higher Education, Mohali , Punjab for a period of 1 Year. She did M.SC NURSING [(Medical- Surgical Health Nursing (Neurosciences)] from All India Institute Of Medical Sciences, New Delhi in 2013 and B.Sc NURSING from National Institute Of Nursing Education, PGIMER, Chandigarh in 2010

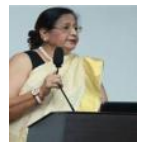

Prof. (Mrs.) Ashia Qureshi is Dean Cum Principal, Galgotias College of nursing, Galgotias University, Greater Noida, U.P. She did Post Graduation in Nursing (Community Health Nursing) from RAK College of Nursing in 1990. Graduation in nursing from AIIMS, New Delhi and Post Graduate Degree in Hospital Administration (MBA). 43 years of successful Nursing services ,nursing education (Lecturer) and Nursing Administration at All India Institute of Medical Sciences (AIIMS) New Delhi 1972. Received Excellence award for best community health services during 'International Conference on Epidemiology' organized by Manipal Medical Academy at Pokhra, Nepal in April ,2017. She received award for Extraordinary Contribution to the field of Nursing Mahila Shiromani National Award from President of India Dr. Shankar Dayal Sharma in president house. Rajiv Gandhi Excellence Award from Health Minister of India and Active life member of Trained Nurses' Association of India. She is Editor-in- chief of 'International Journal of Nursing care' and Member of National Editorial Board of 'International Journal of Nursing education'. She is Examiner in various Universities for the Nursing Course. She published a Research Article/ manuscript in Indian Journal of Surgery care on the topic "A Prospective Randomized Study to Compare the Effectiveness of Honey Dressing vs. Povidone Iodine Dressing in Chronic Wound Healing"; Volume 76, Issue 3, June 2014 and published a Research Article/ manuscript in Asian Journal of Nursing Education and Research on the topic "Effects of Earplugs and Eye Masks on Perceived Quality of Sleep during Night among Patients in Intensive Care Units" ; Volume - 5, Issue3, July-Sep 2015 